\title{
Inuit and Local Knowledge on the Marine Ecosystem in Ilulissat Icefjord, Greenland
}

\author{
Sascha Schiøtt ${ }^{1}$ (i) $\cdot$ Pelle Tejsner ${ }^{2} \cdot$ Søren Rysgaard ${ }^{2}$
}

Accepted: 3 October 2021 / Published online: 25 October 2021

(c) The Author(s) 2021

\begin{abstract}
The interview survey conducted in Ilulissat, Ilimanaq, and Qasigiannguit in Greenland during March-April 2019 showed that the local fishers are changing fishing strategies and adapting to a changing environment caused by climate change. The main fjord of Ilulissat Icefjord is usually filled with icebergs year-round, making it impossible to navigate. Currently, there are more ice clearing events in Ilulissat Icefjord during the winter than previously. The traditional pattern of going fishing using dogsled is changing and fishing from boats occurs, whenever the main fjord clears of ice. The poorer sea ice conditions in the southern branch of the fjord system, combined with the fact that it is increasingly challenging to reach fishing sites, have resulted in fishers from Qasigiannguit not going to the Icefjord as much as they used to. Ilulissat Icefjord is by any means considered important fishing and hunting ground by locals, as both Greenland halibut and ringed seals are known to be of larger size inside the fjord system, when compared to those caught in Disco Bay. The locals use Ilulissat Icefjord during a limited period of the year, and the fjord is therefore said to be protected from overexploitation. They observe the immediate effects of climate change from changes in the ice conditions, a change in the fjord's accessibility, and the occurrence of Atlantic cod, which were not present in the fjord system in such numbers before.
\end{abstract}

Keywords Indigenous knowledge $\cdot$ Traditional knowledge $\cdot$ Greenland $\cdot$ Sermeq Kujalleq Glacier $\cdot$ Climate change

\section{Introduction}

Ilulissat Icefjord (henceforth referred to as the 'Icefjord') fed by the Sermeq Kujalleq glacier (henceforth referred to as 'the glacier') represents an iconic picture of climate change, with massive glacier fronts and iceberg discharge. As the Arctic experiences changes and shifting climates, more knowledge about the glacial fjord's ecosystem and how it is influenced by climate change is needed. The glacier is among the most active in the Arctic, and due to the high presence of icebergs in the fjord, little research of the

Sascha Schiøtt

sasc@natur.gl

Pelle Tejsner

tejsner@bio.au.dk

Søren Rysgaard

rysgaard@bio.au.dk

1 Greenland Institute of Natural Resources, Kivioq 2, 3905 Nuussuaq, Greenland

2 Arctic Research Centre, Aarhus University, Ole Worms Allé 1, bldgs. 1130-1134-1135, 8000 Aarhus, DK, Denmark
Icefjords marine ecosystem has taken place. The dangers of navigating among icebergs and the fact that the main fjord is closed off by icebergs much of the year have limited research vessels from accessing the fjord. The fjord system is used as a fishing and hunting ground by locals during winter and spring, when traveling with dogsled is the main form of transportation across the fjord system. These conditions make the use of local knowledge about the fjord's ecosystem a valuable resource, which complements the limited scientific knowledge about the marine ecosystem of Ilulissat Icefjord. The use of local ecological knowledge has potential for empirical observations, pattern recognition, linking interrelations, and predicting future outcomes (Rosendahl, 1961; Usher, 2000). The use of local Greenlandic knowledge is thus valued. It is customary for fishers/hunters in Greenland to start fishing/ hunting from an early age, usually following the path set forth by their fathers and grandfathers. Therefore, they maintain and practice firsthand knowledge and experiences with seasonal, annual, and interannual changes and can therefore sense the local impacts of climate change. During the winter, the Icefjord is used as a fishing and hunting 
ground by fishers and hunters from the surrounding settlements. Their observations of environmental and ecological changes and their knowledge about the living resources can be used to describe the fjord's ecosystem and document seasonal changes and variations in a fjord system that is otherwise difficult to access by research vessels.

The Icefjord has been an important hunting ground for local Inuit hunters for many generations and remains so today. Archeological excavations have shown that the area was inhabited by Inuit as far back as 4000 years ago, where their primary food sources were of marine origin (Meldgaard, 2004). Catch statistics from the area are also available from 1862 , showing seasonal variation in the availability of different prey, indicating the seasonal movement of different prey species (Rosendahl, 1961; Hamilton et al., 2000). The statistics also show that these different prey species were affected by changes in temperatures. Marine mammals and fish moved northward during warmer periods and southward during colder periods (Hamilton et al., 2000; Rosendahl, 1961). Climate change could result in a shift in the ecosystem, as species usually found in more southern regions could move further north, and thereby cause changes in the local ecosystem, replacing species that used to dominate the region.

The Arctic Council has made repeated calls for the acknowledgment and, where possible, inclusion of local or indigenous knowledge in environmental monitoring and biodiversity assessment where scientific knowledge is lacking due to access issues (Thornton \& Sheer, 2012; Meltofte, 2013; Danielsen, 2014). Terms of usage such as traditional, ecological, or indigenous knowledge have been confused over the years. In this article, we use the term indigenous to best capture the knowledge shared among Kalaallit Inuit hunters and their families (see also Dahl \& Tejsner, 2021). Indigenous knowledge of the fjord ecosystem can be used to assess what to expect in the future and how the fjord system may develop, if climate change continues to impact the local marine ecosystem. Knowledge about these topics may address specific conditions and fluctuations that can be used to better foresee future activities and avoid overfishing or be used to assess changing abundances of local species that are of social and economic interest. Indigenous knowledge may complement scientific knowledge in areas where cause-and-effect processes or local dynamics governing ecosystems such as the Icefjord remain incomplete (Danielsen et al., 2014). Indigenous knowledge also reveals adaptive strategies to a changing environment, which may complement relevant interdisciplinary research on social and natural resource dynamics and stages of equilibrium (Tejsner \& Veldhuis, 2018). This article is based on the shared knowledge about the living resources in Ilulissat Icefjord by local informants and their observations of changing conditions and is therefore not a scientific assessment of the living resources or the fishery policies.
The Icefjord lies adjacent to Disco Bay, which has been studied extensively by Greenland Institute of Natural resources for decades. In contrast, Ilulissat Icefjord has not been studied to the same extent due to the ice conditions limiting activities from vessels. The Icefjord is known for being unique by local people. For example, Greenland halibut, Reinhardtius hippoglossoides (henceforth, 'halibut'), and ringed seals, (Phoca hispida), are known to be larger inside the Icefjord compared to those caught in Disco Bay. The Icefjord is a valuable source for the local fishers/hunters. The current state of the halibut fisheries in Disco Bay is becoming more unstable, visible in decreasing fish length and lower fishing efficiency (Nygaard, 2019).

\section{Physical Properties of Ilulissat Icefjord}

The main fjord Kangia branches out to the north into Sikuiuitsoq and to the south into Tasiussaq and has four marineterminating glaciers. The glacier in the main fjord, the Sermeq Kujalleq glacier, is the most active in the fjord system. The glacier is among some of the most productive in the Arctic regarding icebergs (Tang et al., 2004), which is also why the main fjord is on the UNESCO world heritage list (Weidick et al., 2004). The main fjord is the deepest part of the fjord system, with a uniform depth of 750-800 m, while the northern branch has a maximum depth of around $500 \mathrm{~m}$ and the southern branch with a maximum depth of around $200 \mathrm{~m}$ (Stevens et al., 2016). The sill at the entrance to the main fjord is 150-245 m deep (Gladish et al., 2015), while the sill at the entrance to Tasiussaq is only $70 \mathrm{~m}$ in depth (Stevens et al., 2016). As the glacier is highly active during spring and summer, human activities inside the fjord system are limited to the winter and spring. An exception to this is the activities in the southern branch during the summer, in which residents from Ilimanaq travel into the southern branch through the land, switching to boats inside the fjord to fish for Arctic char (Salvelinus alpinus). At the very southern part of the fjord system, an ice-dammed lake called Tiningnilik is known to empty into Sarqardleq on an average interval of c. ten years (Furuya \& Wahr, 2005). The lake level change is approximately $85 \mathrm{~m}$ during a draining event and a water volume loss is around $2.3 \mathrm{~km}^{3}$.

Residents from Oqaatsut, Ilulissat, Ilimanaq, and Qasigiannguit have used the fjord system as a fishing and hunting ground. Oqaatsut has 30 inhabitants, Ilulissat 4.630, Ilimanaq 53, and Qasigiannguit has 1.086 inhabitants (Fakta om kommunen, 2020a, b October 22).

It is prohibited to use motorized vehicles on the sea ice in the protected areas of Ilulissat Icefjord (Hjemmestyrets bekendtgørelse nr 10 af 15. Juni 2007 om fredning af Ilulissat Isfjord), which necessitates the use of dogsleds when moving around in the Icefjord. 


\section{Methods}

The field campaign took place from the end of March to the first half of April 2019 in Ilulissat, Ilimanaq, and Qasigiannguit. Oqaatsut was not included due to the lack of information about any fishers/hunters from Oqaatsut that currently go to the Icefjord (Oqaatsut is a settlement in decline with only 30 current inhabitants). The study only included fishers/hunters who use the Icefjord as a fishing/ hunting ground.

The interview survey aimed to document the informant's knowledge about the living resources in the Icefjord, and to document their knowledge about changing conditions. Therefore, we announced that the interview survey was to complement scientific research by integrating indigenous hunters' ecological knowledge about a fjord system with limited scientific research. We announced the trip on the national Greenlandic radio KNR, through KNAPK
(Kalaallit Nunaanni Aalisartut Piniartullu Kattuffiatorganization of fishers and hunters in Greenland), posters on bulletin boards, and posts on local Facebook pages. Despite these announcements, the most effective way of getting informants to participate was to meet them in the streets and start a conversation. The interview survey was also used qualitatively to document the collective knowledge shared among the informants. For this reason, the number of informants sharing the same observation/knowledge was used to describe whether a piece of knowledge is broadly accepted or only shared by a few informants. The interviews were conducted with one informant at a time to minimize the influence others could have on their answers and prioritize their firsthand observations.

Despite the aim of interviewing one at a time, three of the interviews were conducted in a hunting cabin on the northern branch of the Icefjord at Augtartup sarqâ, in the presence of other informants, which could have influenced

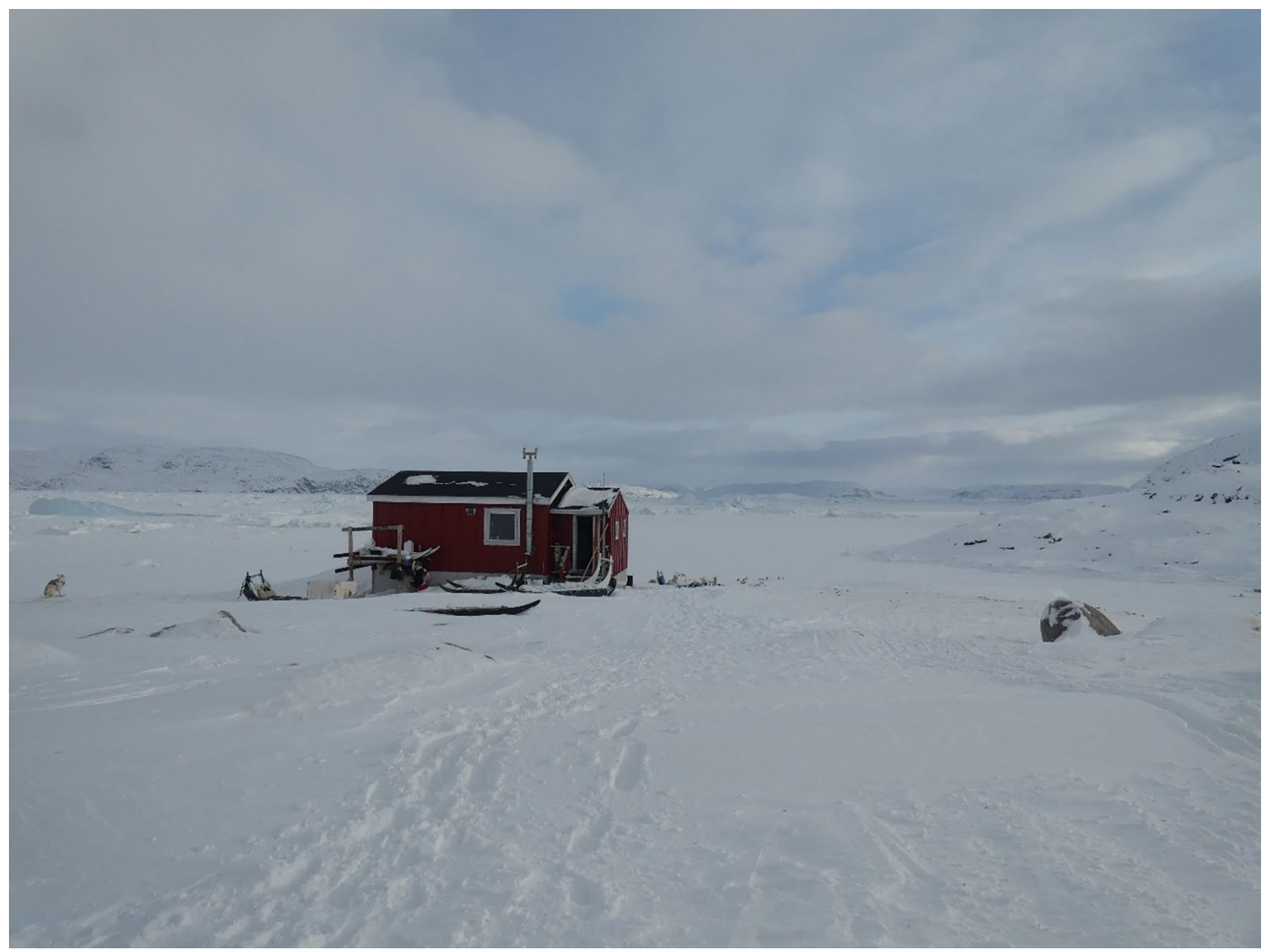

Fig. 1 Hunting cabin at Augtartup sarqâ, with a view over the northern branch of the Icefjord, where three of the interviews were conducted (Photo: Sascha Schiøtt) 
the answers provided (Fig. 1. The hunting cabin). We conducted fieldwork in the northern branch, visited the hunting cabin, and took the opportunity to interview those who were present, making it necessary to interview in the presence of others. At the beginning of each interview, we told the informant that our research questions were designed to record their perceptions and knowledge about the Icefjord. We asked them to locate and draw out areas mentioned on a pre-printed map (Fig. 2). The interviews were in Greenlandic since both interviewers are native speakers (one exception was a resident danish fisher who had fished in the area in the last two decades). Informants have been anonymized, and names are therefore not used in this article. Each interview lasted between $30-60 \mathrm{~min}$. The questions were predetermined, but most were open-ended. The questions were focused on the Icefjord regarding the location of fishing/ hunting sites, seals, fish, changes to local weather and ice conditions, changes in the occurrence of species, and changes in their fishing/hunting activities. Two new topics were added early during the survey, as it became clear that the informants had noticed changes to the size of icebergs and that the ice clearing events in the main fjord during winter had become more frequent in recent years. Both of the topics were not considered in the initial plan. It should be noted that the informants distinguish between "in the recent years" and "many years ago" (more than $\sim 10$ years ago), as changes in the local conditions became clearer about ten years ago. Therefore, they differentiate between two periods where conditions that were considered normal more than ten years ago are compared to new and changed conditions in recent years. Annual dates are therefore not used in the text.

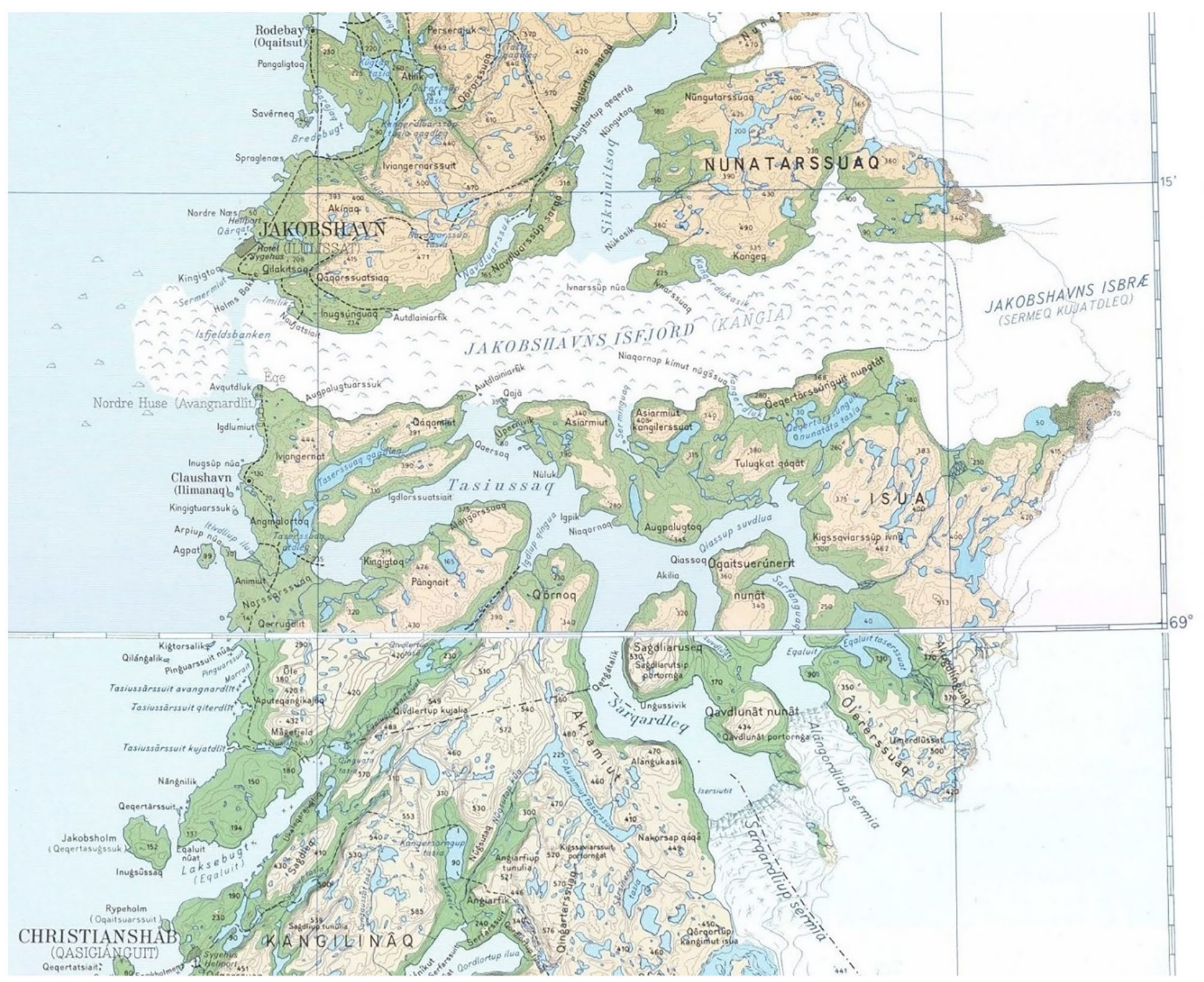

Fig. 2 Map over Ilulissat Icefjord shows the different place names used (note; place names are written with old greenlandic spelling as maps with renewed place names are currently unavailable). Sagamaps 
Table 1 Overview of numbers of interviews in each place visited

\begin{tabular}{lll}
\hline Town/Settlement & Number of Interviews & Interviewers \\
\hline Ilulissat & 17 & Sascha/Bolethe \\
Ilimanaq & 7 & Sascha/Bolethe \\
Qasigiannguit & 9 & Sascha/Bolethe \\
Total & 33 & \\
\hline
\end{tabular}

\section{Results}

\section{The Informants}

A total of 33 informants participated in the survey (Table 1). All informants were male fishers/hunters who use the Icefjord, either for hunting or fishing (Table 1). It is customary in Greenland and the Inuit culture more widely that men go hunting/fishing, and for that reason, we met no female fishers/hunters in the visited settlements. Two of the informants were retired fishers that used to go to the Icefjord regularly, while four informants were recreational hunters that only hunt seals in the fjord, while the rest of the informants were subsistence-based fishers (Fig. 3; age distribution). Their fishing activity in the Icefjord lasts from October/November to April/May, when the snow and ice conditions in the Icefjord are favorable (Fig. 4). During the rest of the year, they fish on the west coast of Greenland. Most of them go by dogsled on land and sea ice into the fjord where they fish from the sea ice. Others fish from boats, or small fishing vessels in the main fjord, where they are restricted to the main fjord and limited by the extent of the sea ice and the ice clearing events.

All informants had started fishing/hunting since childhood/puberty, taught by their fathers and grandfathers.
Therefore, many of them also tenured to fishing sites, which their father/grandfather used as a regular fishing ground before them, and therefore could sense changes over the years. Informants from Ilulissat use the northern branch and the main fjord, rarely reaching the southern branch of the fjord system. In contrast, informants from Ilimanaq and Qasigiannguit use the main fjord and the southern branch and rarely reach the northern branch. When fishing from the sea ice, they stay close to their respective side of the coast in the main fjord (see Fig. 5), for security reasons, as the sea ice can start to move or break up and staying closer to their respective coast means better security.

\section{Past and Present Ice Conditions}

All informants shared the observation that the sea ice generally has become thinner (Table 2), and these types of observations often echo similar testimonies elsewhere among Inuit in the Arctic (Berkes, 2000; Krupnik et al., 2010). Three elder fishers recalled having to dig out holes in the sea ice, as far down as a person could stand, during the 1970s and 1980s, and often these local accounts can be compared to similar observations made elsewhere in Disco Bay (see, for example, Kielsen-Holm, 2010; Tejsner, 2019). The sea ice used to be so thick that they had to carve out staircases on the sea ice to be able to reach the bottom of the sea ice. Nowadays, the sea ice rarely exceeds $1 \mathrm{~m}$. Seventeen informants noted that the main fjord has started to clear out of ice more often now during the winter and that this did not happen to the same extent before. The sea ice in the main fjord has, in recent years, started to break up and clear out a couple of times during the winter with varying degrees (Fig. 6). Therefore, fishers are now more cautious when fishing from the sea ice in the main fjord, as the ice suddenly can
Fig. 3 Ages ranged from 28 to 72 years old, with an average age of 50, and consisted mainly of subsistent fishers/hunters (Four of the informants were recreational hunters out of 33 informants)

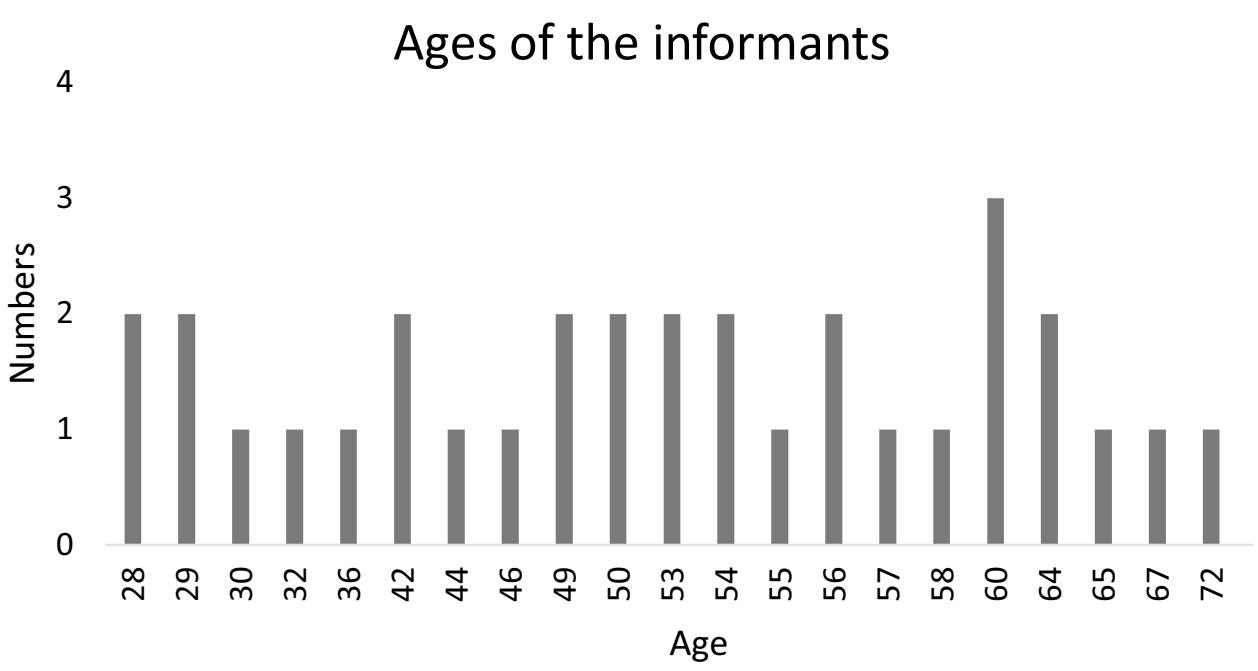


Fig. 4 Fishing activities for each settlement. For the period October-May, the fishing activities are only concerning Greenland halibut. In June and July fishing focuses on Arctic char only, which concerns the fishers from Ilimanaq. The activities in the fjord start in October when sea ice formes, and it is possible to travel into the Icefjord

\section{Fishing/hunting activites in Ilulissat Icefjord}

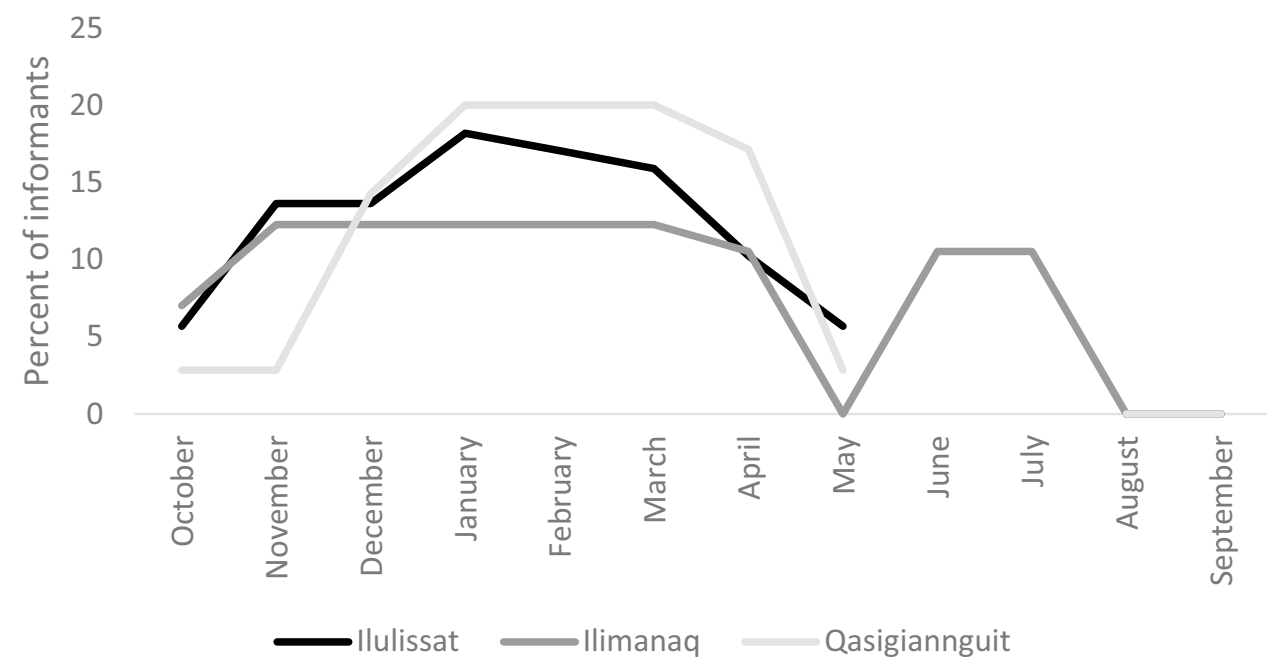

move or break, and they have a higher risk of losing fishing equipment or become trapped between ice floats. Two informants witnessed an ice clearing event firsthand, which they subsequently needed rescuing from, as they got trapped on ice floats and started to drift outwards.

During January-April 2019, at least three ice clearing events occurred in the main fjord, where the sea ice broke up and left the fjord. Sea ice and icebergs drifted out of the Icefjord and into Disco Bay, clearing a large area in the main fjord of ice within days (interpreted from Sentinel-2 satellite images), with the event shown in Fig. 6 being the most robust. The fishers have easier access to information about these ice clearing events now, by looking up ice maps at the Danish Meteorological Institute's webpage, on the Facebook page of "Halibut Greenland", which is a fish factory coowned by several fishers, where weather forecasts and ice maps are shared, or through communication through VHFradios among fellow fishers. This network essentially acts as a communication hub for relaying valuable observations of ice and weather conditions and reports on the sighting of animals in the vicinity of everyday travelers and hunting parties. They, therefore, take the opportunity to sail in whenever the main fjord clears of ice, instead of going in with dogsled through land and sea ice.

Seventeen informants had different theories as to why ice clearing events have become more common. Among the observed changes were thinner sea ice, icebergs generally becoming smaller and therefore rarely grounding at the sill, at the entrance to the main fjord, and a higher presence of smaller icebergs that induce movements in the sea ice, causing the sea ice to break up. Several informants had thoughts that the combination of these changes has resulted in more frequent ice clearing events. One mentioned that the ice clearing events happen when huge waves from outside the fjord travel into the fjord and induce break-up of the sea ice. Another had the hypothesis that calving events at the glacier front could induce sea ice break-up. Eleven of the informants said that the icebergs generally have become smaller. The largest icebergs, which the locals call Maniilaq or Maniitsoq--roughly translated as a massive iceberg with several peaks--have become less abundant today. These huge icebergs often block the entrance to the Icefjord as they run aground at the sill at the entrance to the main fjord, thereby slowing the outflow of ice from the main fjord. As icebergs become smaller, the chances of the icebergs grounding at the sill become lesser, while the chances of the ice clearing out of the fjord increase.

Fishing/hunting activities in the fjord usually start with enough snow on land for the fishers/hunters to travel on with dogsled or snowmobiles. Some informants recalled going into the Icefjord through land earlier than they do today, starting their fishing/hunting activities in October. Nowadays, the ice and snow conditions are more favorable and safe enough to travel during November. Because of these changes, human activities inside the fjord system occur during a shorter season than ten years ago.

\section{Lake Tiningnilik}

Seven informants said they noticed halibut disappear from Tasiussaq when the ice-dammed lake Tiningnilik empties into the southern fjord at Sarqardleq. The informants said that they could sense this by muddier waters, in which two informants mentioned that they could sense that the sea had freshened. One of them had been in Lake Tiningnilik three times, where one 


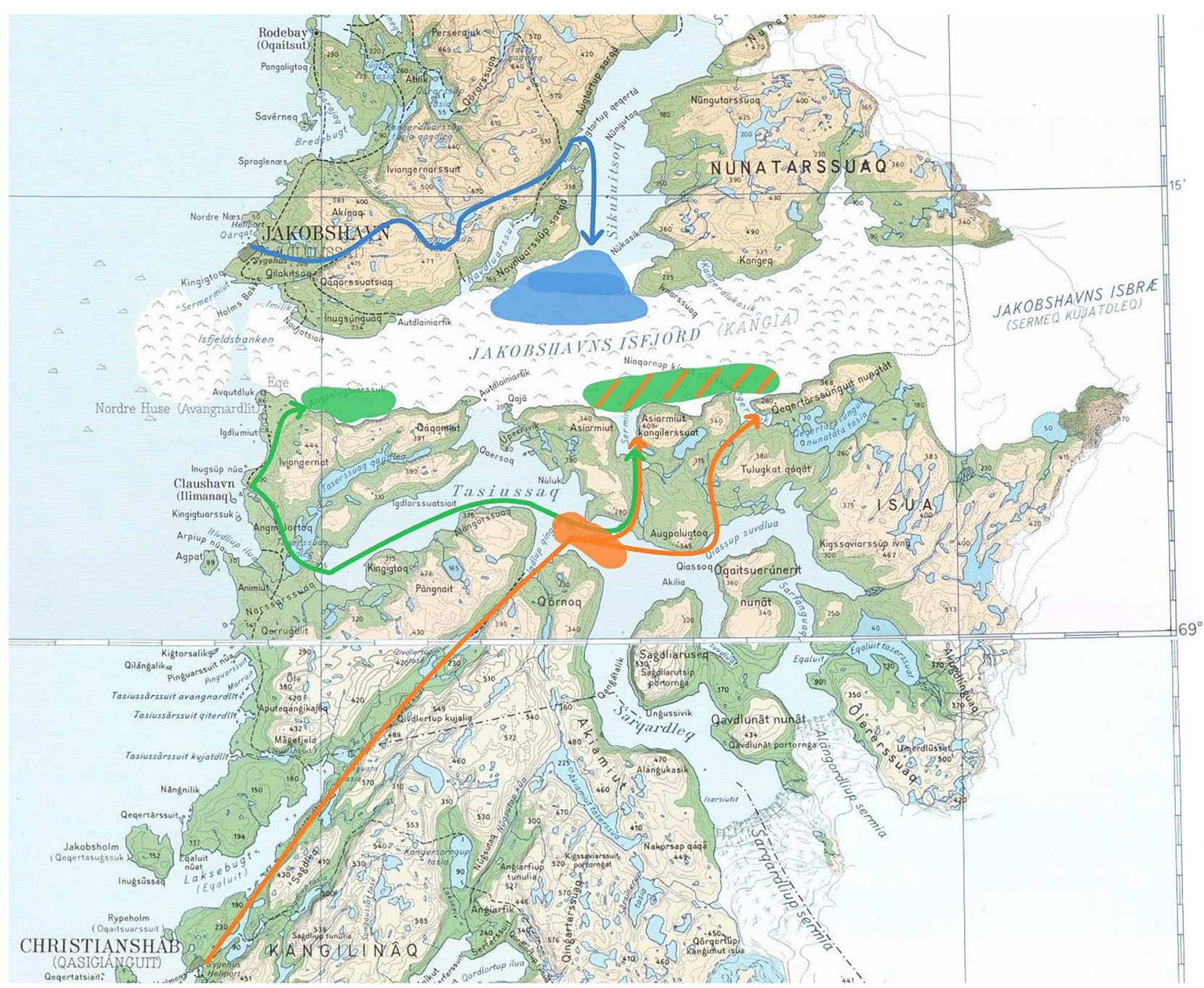

Fig. 5 Shows the main routes and usual fishing ground for those going with a dogsled, fishing for Greenland halibut. Routes are drawn according to the information given by the informants. Ilulissat (Blue), Ilimanaq (Green) and Qasigiannguit (orange). The fishing grounds for

was shortly after a draining event, where he could see how much the water level had changed and observed the muddy lake bottom revealed after the draining event. Others reported some "worm-like organisms" in Tasius$s a q$ after a draining event and how a "transparent yellowish slime" becomes more frequent following these events. The informants have noticed that this slime affects their fishing negatively, as the slime encloses their baits and seems to prevent the halibut from taking the bait and that they catch fewer halibut. During a field excursion in summer 2019, colonial Phaeocystis were observed in the northern branch of Ilulissat Icefjord by the first author, which was also confirmed from an eDNA study (Schiøtt et al., unpublished). They were likely similar to the organisms observed as a "slimy substance" by the informants.
Ilimanaq and Qasigiannguit overlap in one of the areas (striped). The darker and smaller blue area shows where the fishing activity in the blue area is highest

\section{Fishing Activities}

All informants shared the observation that halibut in the Icefjord generally are bigger than the ones they catch on the west coast of Greenland. The halibut are bigger in the main fjord compared to the northern and southern branch. Four informants explained that the smaller halibut are less abundant, the further in they go in the main fjord. The fish community becomes less diverse and dominated by larger halibut the closer they get to the glacier front in the main fjord. The main fjord closes with icebergs during spring and summer and opens to a variable extent when land-fast ice forms during late autumn. The main fjord is inaccessible for six months on average for human activities and only becomes accessible from October/November until April/ May. An exception to this is the fishing activities for Arctic 
Table 2 Overview of the main observed features of Ilulissat Icefjord and observed environmental changes described by the informants

\begin{tabular}{|c|c|}
\hline Main topics & Comments \\
\hline Ice conditions & $\begin{array}{l}\text { Sea ice forms later and melts earlier than before } \\
\text { The main fjord experiences ice clearing events more frequently now, where sea ice and icebergs leave the main fjord within } \\
\text { few days } \\
\text { The sea ice in Tasiussaq forms later and has become unpredictable and unsafe } \\
\text { Icebergs have generally become smaller, and therefore do not ground at the sill at the entrance to the main fjord as much as } \\
\text { before and leave the fjord much faster }\end{array}$ \\
\hline Safety & $\begin{array}{l}\text { The chances of being caught in an ice break up in the main fjord have increased, so fishers stay close to their respective coast } \\
\text { in the main fjord when fishing from the sea ice, to be able to reach the land faster, in case the sea ice starts to break up } \\
\text { Fishers from Qasigiannguit no longer go to the Icefjord as much as before due to unpredictable and unsafe sea ice conditions } \\
\text { in Tasiussaq }\end{array}$ \\
\hline Accessibility & $\begin{array}{l}\text { Fishers start to go into the Icefjord later than they used to, in which fishing activities now usually start during November, } \\
\text { which is later than compared to } 10-20 \text { years ago where activities usually started during October } \\
\text { Fishers from Ilulissat have started using snowmobile drivers to transport their catch to Ilulissat, enabling them to stay longer } \\
\text { inside the Icefjord to fish for more } \\
\text { Fishers from Qasigiannguit no longer go to the Icefjord as much as they used to. Fishers from Qasigiannguit also use the } \\
\text { Icefjord for a shorter period compared to fishers from Ilulissat and Ilimanaq, where they start to go to the Icefjord during } \\
\text { December }\end{array}$ \\
\hline Fish & $\begin{array}{l}\text { Halibut are generally bigger in the main fjord and bigger than the ones in Disco Bay. The halibut are bigger the further in you } \\
\text { go in the main fjord, where smaller individuals also become less abundant and the fish community less diverse and domi- } \\
\text { nated by bigger halibuts the closer you get to the glacier front } \\
\text { Atlantic cod has become more abundant in the Icefjord, which has not been observed in the same extent before } \\
\text { Arctic char migrates into the southern branch during June-July to spawn }\end{array}$ \\
\hline Seals & $\begin{array}{l}\text { Ringed seals in the Icefjord are different from the ringed seals in Disco Bay and are generally bigger and appear visually } \\
\text { different } \\
\text { Ringed seals are hunted either with seal nets placed under the sea ice or with rifles whenever they are sighted on the sea ice } \\
\text { Harp seals are seasonal visitors and are present in the open water masses in the Icefjord and usually are not encountered in } \\
\text { areas covered by sea ice. Harp seals are mainly hunted with rifles when sighted on the sea ice edge or in open water }\end{array}$ \\
\hline Lake Tiningnilik & $\begin{array}{l}\text { Furuya and Wahr (2005) documented that the ice-dammed lake drains into the southern branch with an approximated interval of } \\
10 \text { years. The informants have observed that the halibut disappear, while "worm-like organisms" and a "transparent yellowish } \\
\text { slimy substance" become more frequent following these events. These events negatively affect the fishing activities, as they } \\
\text { seem to prevent the halibut from taking the bait, while also becoming less abundant. The informants can tell when the lake has } \\
\text { emptied by observing more muddy waters and freshening of the water masses }\end{array}$ \\
\hline
\end{tabular}

char (Salvelinus alpinus) in the southern branch during summer, by fishers from Ilimanaq, as they can access the fjord by driving ATVs and using boats located in Tasiussaq. Fishing for Arctic char only happens during June-July

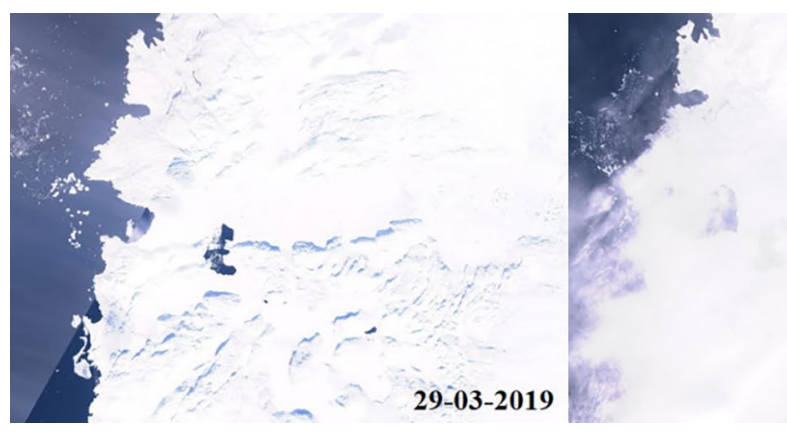

Fig. 6 Images from the open-access GIS hub "Sentinel hub". Sentinel-2 satellite images of Ilulissat Icefjord, showing the sea ice breaking up in the main fjord. Images from the period 30-03-2019 to 08-04-2019 were when the fish migrate into the fjord to spawn (Fig. 7 : fishing spots for Arctic char). Fishers from Ilimanaq are in this context privileged, as they are the only ones able to access the fjord system during the summer. The fjord system is

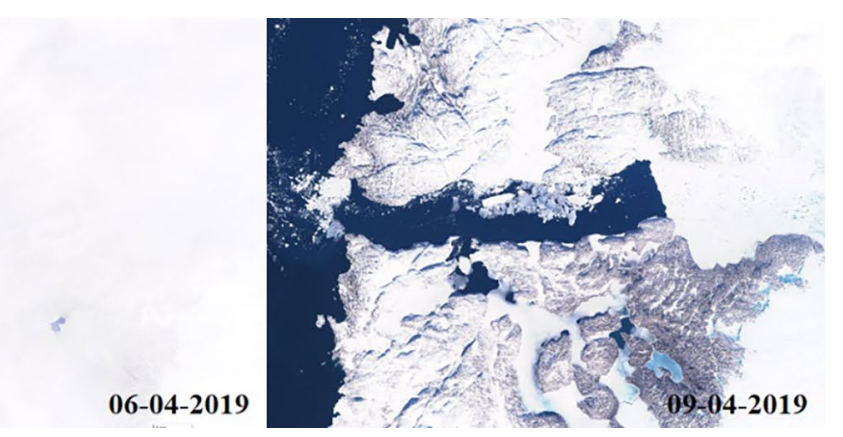

covered with clouds, and the image from 06-04-2019 was the clearest one, were the ice edge shows. Within three days, a considerable part of the main fjord was cleared of ice 


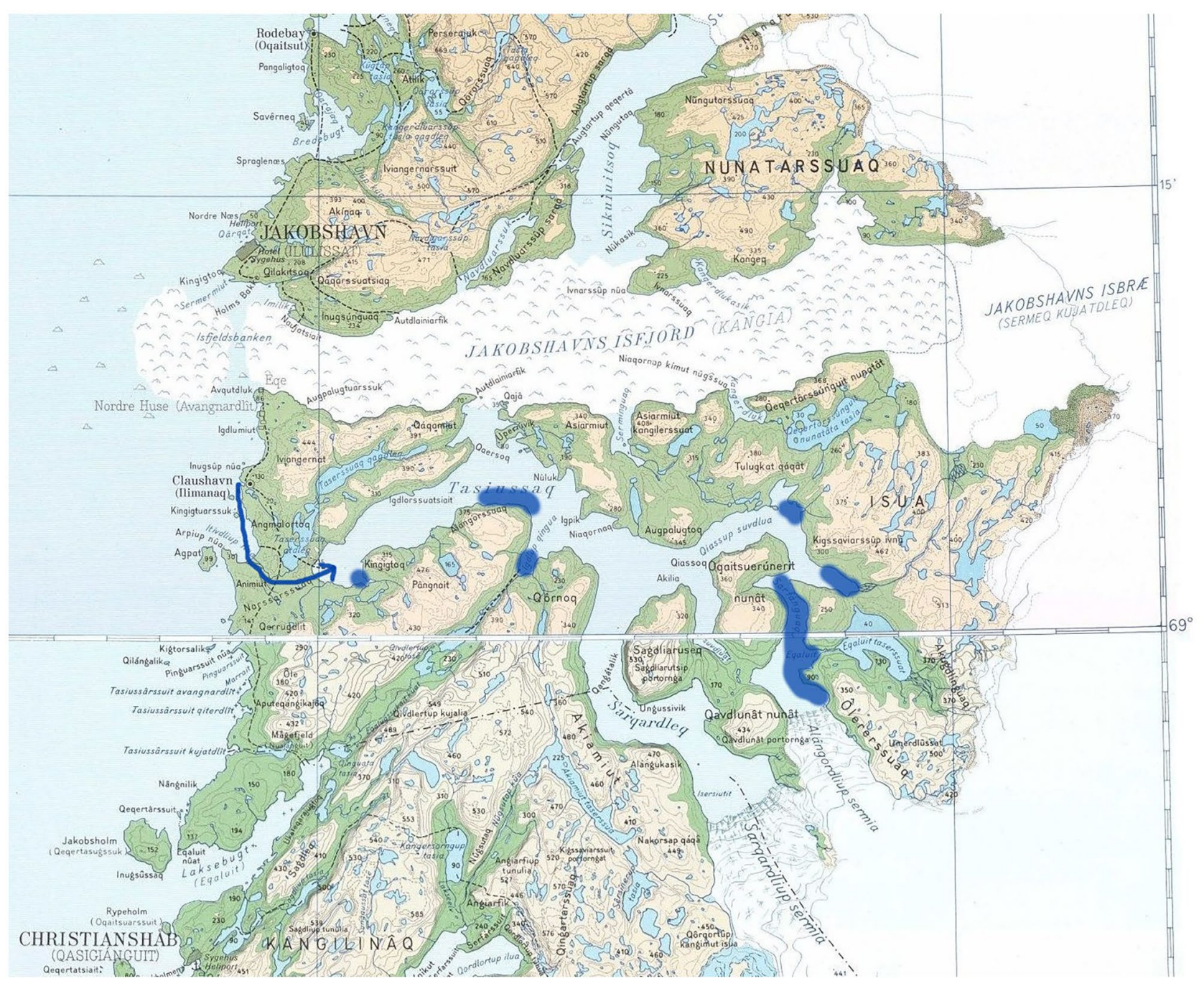

Fig. 7 Main route and locations of where fishers from Ilimanaq fish for Arctic char during June - July. Route and locations are given by informants from Ilimanaq

almost inaccessible from late spring to late autumn due to the exposed rough and mountainous terrain. The exception being scientists and tourists going into the fjord by chartered helicopters.

\section{Changing Environmental Conditions}

Some informants had recently stopped going fishing with dogsled over land and sea ice, and fish from boats instead. The reason is that the sea ice in the main fjord has become thinner and unpredictable. The fjord has become more open and accessible from sea in recent years (Fig. 8). The sea ice in Tasiussaq has started to form later and has become unpredictable and unsafe to travel on, which is an observation shared by informants from Ilimanaq and Qasigiannguit. For this reason, fishers from Qasigiannguit no longer go to the Icefjord as much as they used to. Five informants from Qasigiannguit reported that they no longer go fishing in the Icefjord in recent years because of the ice conditions and instead fish in other places. We also met fishers from Qasigiannguit who did not wish to participate in the survey. They had not fished in the Icefjord for several years since it has become difficult to reach the fishing sites by dogsled.

\section{Atlantic Cod}

Nine informants mentioned having caught Atlantic cod (Gadus morhua) in the Icefjord in recent years, which they had never caught before, and observed that their numbers had increased steadily. Some were concerned that the Atlantic cod would become more numerous inside the Icefjord in the future. They thought that this could negatively affect the halibut stock in the Icefjord and cause 


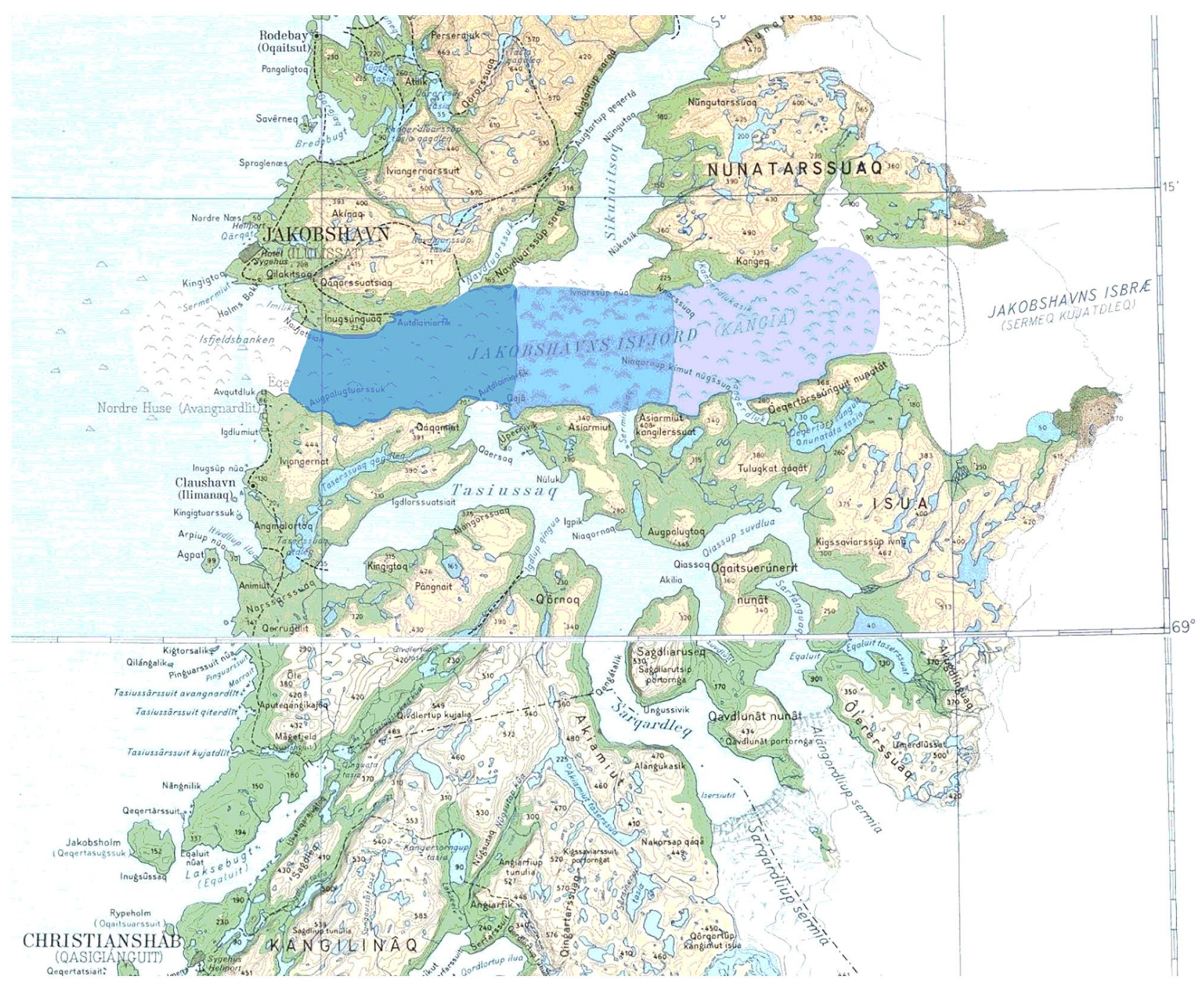

Fig. 8 A Variable area in the main fjord where fishing and hunting happens from boats during the winter. Area has been drawn according to the information given by the informants. The size of this area depends on the extent of the sea ice and it only happens during short

some changes in the local ecosystem as these two species could be competing for the same resources.

\section{Seals}

The Icefjord is inhabited by a different type of ringed seals (Phoca hispida) than the ones commonly found on the west coast of Greenland. All informants described the ringed seals from the Icefjord as being unique, bigger, and different from the ringed seals they catch outside the Icefjord. Differences mentioned were more prominent spots, darker snout, darker meat, and stronger taste, but overall that these ringed seals are bigger than the ringed seals on the west coast. Some described their size as being closer to the size of an adult harp seal, which the ringed seals from outside the fjord rarely periods where the ford is open and with higher frequency in the darker blue area. Sighted harp and ringed seals in the sea or at the sea ice margin are also shot from boats in this area

reach. They distinguish the two ringed seals by calling them different names: Kitaajaqqat for the ringed seals from the west coast - translated as the small ones from the west-- and Natsillaat for the ringed seals from the Icefjord-translated as the big ringed seals. They usually can tell when the ringed seals from the west coast have entered the fjord or when the ringed seals from the Icefjord drift out with the outflowing ice from the main fjord by morphologically assessing the seal. Some say that they prefer to eat ringed seals from the Icefjord: "Natsillaat ilittoqqussarigakkit mamarineruakka"/ 'I have grown up eating ringed seals from the Icefjord and prefer their taste', while others prefer ringed seals from the west coast, not liking the ringed seals from the Icefjord: "Natsillaat tiggannittuuput, uanga mamarisarinngilakka"/ "The 


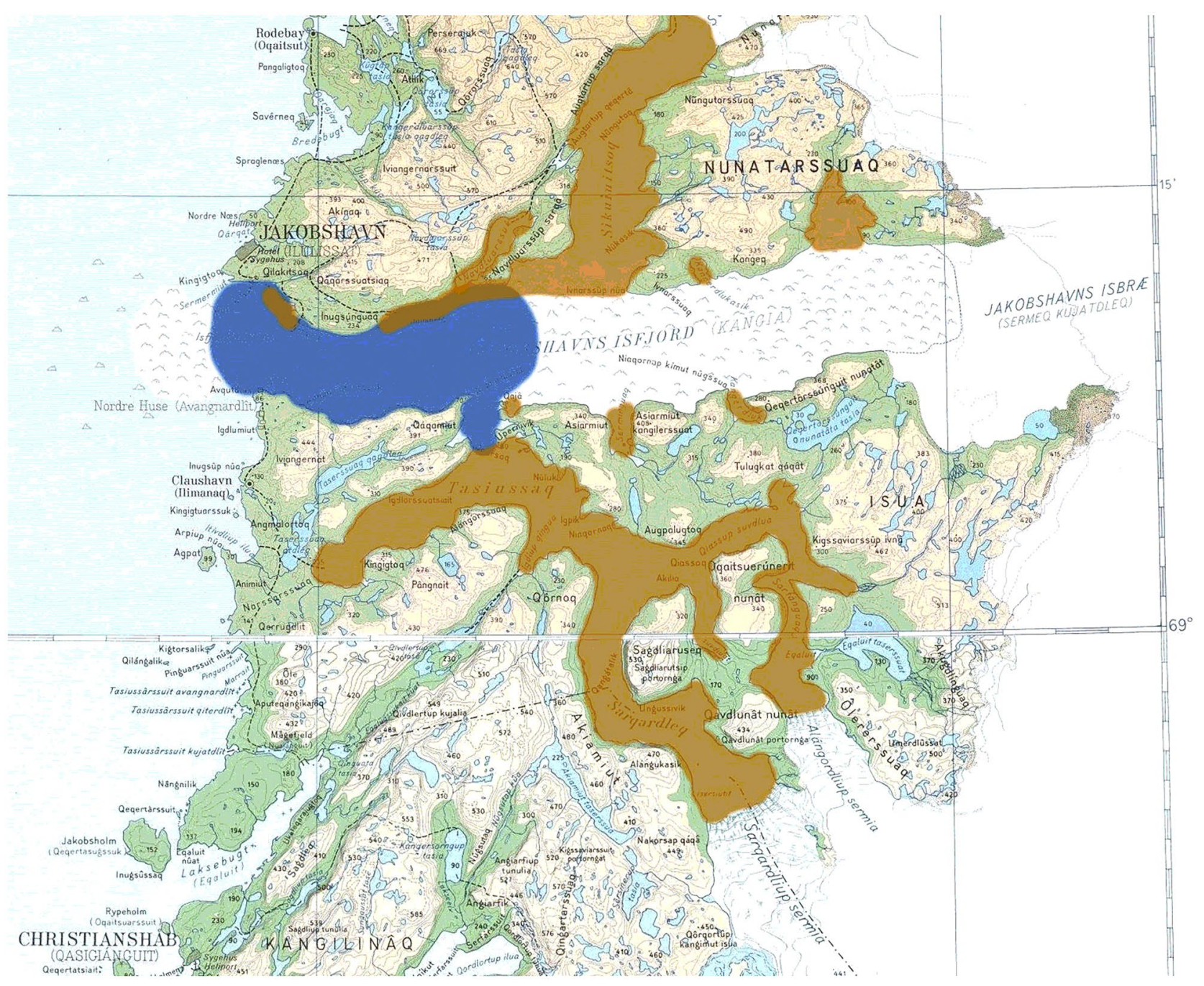

Fig. 9 Shows the main areas where seals are caught. The blue area shows the main area for harp seal hunt within open water, while the orange areas are where ringed seals are hunted from dogsled on sea ice-drawn according to the information given by the informants

ringed seals from the Icefjord have a strong odor, and I do not like the taste.'

The area around Sarfaa, at the entrance to Tasiussaq, has an open water polynya during the winter due to the high currents around the shallow sill. The sea ice close to the polynya is generally dangerous, as the ice is thin. Informants from Ilimanaq were the only ones noticing a change in the abundance of the ringed seals, as four informants from Ilimanaq said that the ringed seals used to be more abundant in Tasiussaq. These informants also had to change the locations where they place their nets to catch ringed seals, as their usual hunting places now have bad sea ice conditions and are unsafe to travel on. The informants from Ilulissat and Qasigiannguit did not report changes to the abundance of the ringed seals in the Icefjord.

Other seal species seen inside the fjord system are mainly harp seals (Phoca groenlandica) that come inside the main fjord and around the open water polynya at Sarfaa, at the entrance to the southern branch, when the sea ice retreats or breaks up. The harp seals are usually only present in open water masses and usually are not encountered in areas covered by fjord ice. The harp seals that occasionally pay a visit to areas with no sea ice are seasonal visitors visiting the fjord to pursue shoals of capelin (Mallotus villosus) (Fig. 9; main areas where harp seals and ringed seals are caught). These differences in the distribution of ringed seals and harp seals influences where they are caught, as ringed seals mainly are caught in areas with sea ice, while harp seals are caught in open water.

\section{The Fjord's Accessibility}

The locals describe the fjord as being protected by nature, as it becomes impossible to access the fjord from late spring to late fall, when the main fjord closes off with icebergs, 
where it becomes impossible to sail in, or when poor snow conditions on land make it difficult to reach the fjord by land using dogsled. Residents from Ilulissat stop their activities in the northern branch when poor snow conditions on land prevent them from traveling into the fjord, usually around April/May. Four informants described the ecosystem in the fjord system as protected from overexploitation because of the limited time they can access the fjord system. As put by an informant: "Kangia imminut paarivoq"/ "the Icefjord is self-protected.'

The fishers from Ilulissat have now started using snowmobiles to transport their halibut catch to Ilulissat through the land (some hire snowmobile drivers to transport their catch for them). Therefore, the fishers can stay inside the fjord for a longer period, to fish for halibut, and are therefore not bound to have to transport their catch by themselves.

The fjord system is accessible during a shorter period now, compared to more than ten years ago, as fishing activities used to last longer, starting in October and ending in May. Today this only happens during extra cold winters, which are becoming rare. Two informants from Ilulissat recalled staying in the northern branch until May in 2018 and later regretting this, as it had become difficult to go back to Ilulissat due to warmer weather. A specific sloped area on land, close to the hunting cabins in the northern branch, becomes difficult to move on as snow and mud start to slide off when the weather becomes warm. One said: "Anersa kangia maj-imi najoqqillugu: Pisariuallaaqaaq"/ 'I will never be in Kangia during May again: It is too challenging.'

\section{Discussion}

The main change that have occurred in the Icefjord, according to the informants, is the measurable decrease in sea ice thickness and that ice clearing events happen more often now during the winter in the main fjord. The ice clearing events are new, as the main fjord used to be blocked with icebergs year-round and only accessible when land-fast ice was formed. Now fishers can sail instead of going over land and sea ice. Traveling into the fjord with dogsled had been the traditional way of fishing/hunting for many centuries. However, as the main fjord opens more frequently during winter, more fishers will take advantage of this by going with boats instead of dogsled. The use of satellite images to check ice cover has already become more frequently used among fishers and has made it easier for the fishers to follow the ice clearing events in the main fjord. The more frequent ice clearing events become in the future, the easier it will be for fishers going with boats or fishing vessels to go into the main fjord. Traveling with dogsled would, on the other hand, become less frequent, as it would be less safe to travel on the sea ice, which to some extent it already is.
In the context of these observed changes, it is important to monitor the marine ecosystem in the fjord, to see how current changes are influencing species diversity of the fjord's ecosystem, and how the size and abundance of, for example, halibut will be affected, as overfishing might become a relevant issue in the future. This is highly relevant as 27 of the informants are subsistence-based fishers who are highly dependent on their fisheries. Any potential increase in their fisheries will ultimately influence the halibut population in the Icefjord. The halibut in Disco Bay has already shown signs of overfishing as decreasing mean length and lower fishing efficiency of halibut has been documented (Nygaard, 2019), which could also happen in the Icefjord. Therefore, it is also relevant to ask which factors affect the halibut stock most, e.g., whether it is 1) pressure from the fisheries, 2) changing ocean temperatures, 3) changing sea ice conditions, 4) higher presence of harp seals, or Atlantic cod inside the Icefjord, or 5) the results of changing plankton communities. Changes in the plankton community also need to be considered as changing sea ice conditions can initiate cascading events in the food web (Fossheim et al., 2015; Kortsch et al., 2012, 2015; Mueter et al., 2020). Sea ice algae need stable sea ice (Leu et al., 2011, 2015), otherwise their abundance will be affected by changing sea ice conditions. This, in turn, can affect communities of copepods, whereby boreal species will replace arctic species (Møller $\&$ Nielsen, 2019). This, in turn, affects the polar cod, as they have been shown to depend highly on the Arctic copepod Calanus glacialis (Bouchard \& Fortier, 2020). Moreover, as polar cod plays a crucial role in Arctic food webs (Hop \& Gjøsæter, 2013; Mueter et al., 2020), a change in their abundance will potentially affect the abundance of other species higher up in the food chain (Bouchard et al., 2017; Bouchard et al., 2020; Hop \& Gjøsæter, 2013; Mueter et al., 2020). On the other hand, thinner sea ice conditions, more open water and increased freshwater discharge from below glaciers leading to an increase in nutrient transport from deeper waters to the fjord surface may enhance phytoplankton production in the upper stratified water column, that is often nutrient limited during summer as seen in other fjord systems (Meire et al., 2017). This may potentially influence the population of halibut, or the ringed seals that also reside in the Icefjord, through a change in the structure of the food web. The halibut population will most likely also be influenced by a higher presence of Atlantic cod, which some locals have concerns about, as the species has become more numerous in recent years. The Atlantic cod is most abundant in shallow water but can reside in depths of $600 \mathrm{~m}$ (unpublished data, Greenland Institute of Natural Resources). Halibut make daily vertical migrations in the water column occupying depths of 200-800 m in Ilulissat Icefjord (Boje et al., 2014). These two species can therefore potentially exploit similar depths and hence similar prey in the Icefjord. A 
higher presence of Atlantic cod may lead to an interspecific competition between Atlantic cod and halibut for the same resources and as a result of this affect the halibut stock in the Icefjord negatively. Nine informants that began catching Atlantic cod inside the Icefjord reported never having done so in the past, which indicates that changing conditions in the fjords water masses have occurred, as the Atlantic cod migrates further north with increasing ocean temperatures (Drinkwater, 2005). The halibut in the Icefjord has been sovereign in being the primary species caught. However, climate change and a higher presence of Atlantic cod could affect their dominance in the fjord's ecosystem.

Another important change in the food web would be a higher presence of harp seals, resulting in higher interspecific competition with ringed seals, as these two species have been shown to have a significant niche overlap in the Barents Sea (Wathne et al., 2000), which could be similar in the Icefjord. The informants have observed that harp seals are more abundant when a larger area in the Icefjord is ice-free, as harp seals usually migrate in areas with open water (Folkow et al., 2004). Therefore, a higher rate of ice clearing events may lead to a higher presence of harp seals, as they would find a larger open water area, allowing them to exploit the same prey as resident ringed seals. Therefore, future changes to the fjord's ecosystem could be that ringed seals that are unique to the Icefjord may become less abundant due to competition with harp seals for resources. In addition, less suitable breeding habitats with stable sea ice will have a negative effect on their pup survival rate (Ferguson et al., 2005) and consequently their population size. The ice-dammed lake Tiningnilik, which back in 2005 was shown to drain, on an average every 10 years (Furuya \& Wahr, 2005), may experience more frequent draining episodes if the melt rate of the ice cap were to increase due to climate warming, and thereby have a crucial impact on the ecosystem in the southern branch as noted by the locals. The informants mentioned that they observed, "worm-like organisms" and a "slimy substance" in relation to the draining event. This being the result of subglacial discharge causing an upwelling of nutrients and organisms from the sediment to the surface. This upwelling of nutrients from the sediments may potentially stimulate an algal bloom of colonial Phaeocystis that creates a gelatinous structure that is odorous (Schoemann et al., 2005). This may explain what the informants described as a slimy substance that negatively affects their fishing activities. The worm-like organisms could be benthic polychaeta or amphipods brought up from the sediment by the upwelling currents caused by the draining event. Such an event would also result in changes in temperature and salinity conditions in the water masses, killing or displacing fish (such as halibut) that reside near the ice-dammed lake in the southern branch as observed by the locals. This agrees with observations from the Godthåbsfjord system further south where large amounts of relatively warm and saline intermediate water were brought to the nearsurface layers by entrainment processes near the glacier front influencing the hydrography of the fjord but also impacting the ecosystem through upwelling of nutrient-rich intermediate water (Kjeldsen et al., 2014; Meire et al., 2017).

\section{Conclusion}

Ongoing climate change may lead to fundamental changes both to the marine ecosystem in the Icefjord, but also to the strategies used by local fishers, in which a change from traditional fishing using sledge dogs for transportation to and from the fishing grounds moves toward more modern methods in which fishing from boats or vessels becomes dominant. The fishers would be able to travel in and out of the main fjord much faster, and therefore the possibility of a more effective halibut fishery is possible. The halibut fisheries in the Icefjord have been viewed as being protected from overexploitation due to the limited time the fishers can fish inside the main fjord. However, as the main fjord becomes more accessible, a higher fishing efficiency may develop, which can negatively affect the halibut population inside the fjord system. This study also highlights the potential role of climate change on the marine ecosystem in the Icefjord, as changes in the sea ice conditions and warmer waters may bring other species into the Icefjord, initiating cascading effects on the local ecosystem, potentially affecting species higher up in the food chain.

The results of the interview survey also emphasize the value of including indigenous knowledge in research, as their observations and how they have adapted to a changing environment can be combined with science in describing an ecosystem that is otherwise difficult to access and be used to foresee what to expect in the future. Ilulissat Icefjord can potentially be accessed by research vessels in the future, as the ice clearing events present a new opportunity to sail in to conduct surveys, but as these events happen spontaneously, planning is a big challenge for this reason, and thus local knowledge is a valuable resource.

Acknowledgements We greatly thank the local fishers/hunters for participating in the survey and sharing their valuable knowledge. This project was part of a Ph.D. project funded by Aage V. Jensen Charity Foundation, and the Greenland Institute of Natural Resources funded the interview survey as an internal project. A special thanks to Bolethe Skifte Egede, a research technician from the Greenland Institute of Natural Resources, for contributing to the practical part of the survey and for creating a relaxed atmosphere during interviews, which the informants also clearly appreciated. Thanks to Parnuna Egede Dahl for the many discussions on how the interview process can be set up, Aqqalu Rosing-Asvid, senior scientist at The Greenland Institute of Natural Resources, for constructive criticism on some of the aspects of the interview survey, and Johnna Michelle Holding for constructive comments. We thank The Icefjord office in Ilulissat for providing 
an office and Kommune Qeqertalik, for providing an office in Qasigiannguit. Ove Villadsen in Ilimanaq provided accommodation and a place to conduct the interviews in Ilimanaq.

Open Access This article is licensed under a Creative Commons Attribution 4.0 International License, which permits use, sharing, adaptation, distribution and reproduction in any medium or format, as long as you give appropriate credit to the original author(s) and the source, provide a link to the Creative Commons licence, and indicate if changes were made. The images or other third party material in this article are included in the article's Creative Commons licence, unless indicated otherwise in a credit line to the material. If material is not included in the article's Creative Commons licence and your intended use is not permitted by statutory regulation or exceeds the permitted use, you will need to obtain permission directly from the copyright holder. To view a copy of this licence, visit http://creativecommons.org/licenses/by/4.0/.

\section{References}

Berkes, F. (2000). Indigenous knowledge and resource management systems in the Canadian subarctic. In F. Berkes \& C. Folke (Eds.), Linking Social and Ecological Systems (pp. 98-129). Cambridge University Press.

Boje, J., Neuenfeldt, S., Sparrevohn, R., Eigaard, O., \& Behrens, J. W. (2014). Seasonal migration, vertical activity, and winter temperature experience of Greenland halibut Reinhardtius hippoglossoides om West Greenland waters. Marine Ecology Progress Series, 508, 211-222. https://doi.org/10.3354/meps10874

Bouchard, C., Geoffroy, M., LeBlanc, M., Majewski, A., Gauthier, S., Walkusz, W., Reist, J. D., \& Fortier, L. (2017). Climate warming enhances polar cod recruitment, at least transiently. Progress in Oceanography, 156, 121-129. https://doi.org/10.1016/j.pocean. 2017.06.008

Bouchard, C., \& Fortier, L. (2020). The importance of Calanus glacialis for the feeding success of young polar cod: A circumpolar synthesis. Polar Biology. https://doi.org/10.1007/ s00300-020-02643-0

Dahl, P. E., Tejsner. P. (2021). 'Review and mapping of indigenous knowledge concepts in the Arctic'. In Routledge Handbook of Indigenous People in the Arctic. Koivurova, T, Broderstad, E. G., Cambou, D. Dorough, D and Stammler, F. (eds.) Routledge: New York. 233-248.

Danielsen, F., Topp-Jørgensen, E., Levermann, N., Løvstrøm, P., Schiøtz, M., Enghoff, M., \& Jakobsen, P. (2014). Counting what counts: Using local knowledge to improve Arctic resource management. Polar Geography, 37(1), 69-91. https://doi.org/10.1080/ 1088937X.2014.890960

Drinkwater, D. (2005). The response of Atlantic cod (Gadus morhua) to future climate change. ICES Journal of Marine Science, 62, 1327-1337. https://doi.org/10.1016/j.icesjms.2005.05.015

Fakta om kommunen. (2020a). Numbers of inhabitants in Ilulissat, Ilimanaq and Oqaatsut. Municipal office of Avannaata kommunia, viewed 22 October 2020. https://www.avannaata.gl/Emner/Om_ kommunen/Fakta\%20om\%20kommunen?sc_lang=da.

Fakta om kommunen. (2020b). Numbers of inhabitants in Qasigiannguit. Municipal office of Kommune Qeqertalik, viewed 22 October 2020. http://qeqertalik.gl/Emner/Om_kommunen/Fakta\%20om\% 20kommunen?sc_lang=da.

Ferguson, S., Stirling, I., \& McLoughlin, P. (2005). Climate change and ringed seal (Phoca hispida) recruitment in western Hudson Bay. Marine Mammal Science, 21(1), 121-135. https://doi.org/10. 1111/j.1748-7692.2005.tb01212.x
Folkow, L. P., Nordøy, E. S., \& Blix, A. S. (2004). Distribution and diving behaviour of harp seals (Pagophilus groenlandicus) from the Greenland Sea stock. Polar Biology, 27, 281-298. https://doi. org/10.1007/s00300-004-0591-7

Fossheim, M., Primicerio, R., Johannesen, E., Ingvaldsen, R. B., Aschan, M., \& Dolgov, A. V. (2015). Recent warming leads to a rapid borealization of fish communities in the Arctic. Nature Climate Change, 5, 673-677. https://doi.org/10.1038/nclimate2647

Furuya, M., \& Wahr, J. M. (2005). Water level changes at an icedammed lake in west Greenland inferred from InSAR data. Geophysical Research Letters, 32, L14501. https://doi.org/10.1029/ 2005GL023458

Gladish, C. V., Holland, D. M., Rosing-Asvid, A., Behrens, J. W., \& Boje, J. (2015). Oceanic boundary conditions for Jakobshavn Glacier. Part I: Variability and renewal of Ilulissat Icefjord water, 2001-14*. Journal of Physical Oceanography, 45, 3-33. https:// doi.org/10.1175/JPO-D-14-0044.1

Hamilton, L., Lyster, P., \& Otterstad, O. (2000). Social change, ecology and climate in 20th-century Greenland. Climate Change, 47, 193-211. https://doi.org/10.1023/A:1005607426021

Hjemmestyrets bekendtgфrelse nr 10 af 15. Juni 2007 om fredning af Ilulissat Isfjord, viewed 19 March 2021. http://lovgivning.gl/lov?rid=\% 7BC6681D09-AD38-44AA-88C1-0B5F9B0AC554\%7D\#: :text= juni $\% 202007 \% 20$ om $\% 20$ fredning $\% 20$ af $\%$ 20Ilulissat $\% 20$ Isfjord\& text $=\% \mathrm{C} 2 \% \mathrm{~A} 7 \% 201 .$, naturhistoriske $\% 2 \mathrm{C} \% 20$ kulturhistoriske $\%$ 20og\%20\%C3\%B8vrige\%20naturv\%C3\%A6rdier.

Hop, H., \& Gjøsæter, H. (2013). Polar cod (Boreogadus saida) and capelin (Mallotus villosus) as key species in marine food webs of the Arctic and the Barents Sea. Marine Biology Research, 9(9), 878-894. https://doi.org/10.1080/17451000.2013.775458

Holm, L.K. (2010) Sila-Inuk: Study of the Impacts of Climate Change in Greenland. In: Krupnik I., Aporta C., Gearheard S., Laidler G., Kielsen Holm L. (eds) SIKU: Knowing Our Ice. Springer, Dordrecht. https://doi.org/10.1007/978-90-481-8587-0_6

Kjeldsen, K. K., Mortensen, J., Bendtsen, J., Petersen, D., Lennert, K., Rysgaard, S. (2014). Ice-dammed lake drainage cools and raises surface salinities in a tidewater outlet glacier fjord, west Greenland. Journal of Geophysical Research. Earth Surface, 119 https:// doi.org/10.1002/2013JF003034

Kortsch, S., Primicerio, R., Beuchel, F., Renaud, P. E., Rodrigues, J., Lønne, O. J., \& Gulliksen, B. (2012). Climate-driven regime shifts in Arctic marine benthos. PNAS, 109(35), 14052-14057. https:// doi.org/10.1073/pnas.1207509109

Kortsch, S., Primicerio, R., Fossheim, M., Dolgov, A. V., Aschan, M. (2015). Climate change alters the structure of arctic marine food webs due to poleward shifts of boreal generalists. Proceedings of the Royal Society B, 282.https://doi.org/10.1098/rspb.2015.1546

Krupnik, I., Aporta, C., Gearheard, S., Laidler, G. J., \& Holm, L. K. (2010). SIKU: Knowing Our Ice: Documenting Inuit Sea Ice Knowledge and Use. Springer.

Leu, E., Søreide, J. E., Hessen, D. O., Falk-Pedersen, S., \& Berge, J. (2011). Consequences of changing sea-ice cover for primary and secondary producers in the European Arctic shelf seas: Timing, quantity, and quality. Progress in Oceonography, 90, 18-32. https://doi.org/10.1016/j.pocean.2011.02.004

Leu, E., Mundy, C. J., Assmy, P., Campbell, K., Gabrielsen, T. M., Gosselin, M., Juul-Pedersen, T., \& Gradinger, R. (2015). Arctic spring awakening - Steering principles behind the phenology of vernal ice algal blooms. Progress in Oceanography, 139, 151170. https://doi.org/10.1016/j.pocean.2015.07.012

Meldgaard, M. (2004). Ancient Harp Seal Hunters of Disco Bay. Subsistence and Settlement at the Saqqaq Culture Site Qeqertasussuk (2400-1400BC), West Greenland. Meddelelser om Grønland, Man \& Society Vol. 30. Copenhagen, Danish Polar Center. 
Meltofte, H. (2013). Meltofte, H. (Ed.), 2013, Arctic Biodiversity Assessment. Status and trends in Arctic biodiversity (Akureyri, Iceland: Conservation of Arctic Flora and Fauna).

Meire. L., Mortensen, J., Meire, P., Juul-Pedersen Sejr, M. K., Rysgaard, S., Nygaard, R., Huybrechts, P., Meysman, F. J. R. (2017). Marineterminating glaciers sustain high productivity in Greenland fjords. Global Change Biology 1-14. https://doi.org/10.1111/gcb.13801

Mueter, F., Bouchard, C., Hop, H., Laurel, B., \& Norcross, B. (2020). Arctic gadids in rapidly changing environment. Polar Biology. https://doi.org/10.1007/s00300-020-02696-1

Møller, E. F., \& Nielsen, T. G. (2019). Borealization of Arctic zooplankton - smaller and less fat zooplankton species in Disco Bay, Western Greenland. Limnology and Oceanography, 9999, 1-14. https://doi.org/10.1002/lno.11380

Nygaard, R. (2019). Commercial data for the Greenland halibut stock component in NAFO Division 1A inshore. NAFO SCR Doc. 19/032 Serial No. N6949. https://www.nafo.int/Portals/0/ PDFs/sc/2019/scr19-032.pdf

Rosendahl, P. (1961) Grønlands jagt- og fangststatistik. Geografisk tidsskrift 60 . bind 16-38.

Schoemann, V., Becquevort, S., Stefels, J., Rousseau, V., \& Lancelot, C. (2005). Phaeocystis blooms in the global ocean and their controlling mechanisms: A review. Journal of Sea Research, 53(2005), 43-66. https://doi.org/10.1016/j.seares.2004.01.008

Stevens, L. A., Straneo, F., Das, S. B., Plueddemann, A. J., Kukulya, A. L., \& Morlighem, M. (2016). Linking glacially modified waters to catchment-scale subglacial discharge using autonomous underwater vehicle observations. The Cryosphere, 10, 417-432. https://doi. org/10.5194/tc-10-417-2016
Tang, C. C. L., Ross, C. K., Yao, T., Petrie, B., DeTracey, B. M., \& Dunlap, E. (2004). The circulation, water masses and sea-ice of Baffin Bay. Progress in Oceonography, 63, 183-228. https://doi. org/10.1016/j.pocean.2004.09.005

Tejsner, P., \& Veldhuis, D. (2018). Climate Change as (Dis)Equilibrium: Behavioral Resilience in the Greenlandic Arctic. Human Ecology, 46, 701-715. https://doi.org/10.1007/s10745-018-0026-7

Tejsner, P. (2019). "It Is Windier Nowadays": Coastal Livelihoods and Seascape-Making in Qeqertarsuaq, West Greenland. In: At Home on the Waves: Human Habitation of the Sea from the Mesolithic to Today. King, T. J and G. Robinson (eds.). Environmental Anthropology and Ethnobiology Series, Vol 24. Oxford: Berghahn Books.

Thornton, T. F., Scheer, A. M. (2012). Collaborative engagement of local and traditional knowledge and science in marine environments: A review. Ecology and Society 17(3):8. http://www.jstor.org/stable/26269064

Usher, P. (2000). Traditional Ecological Knowledge in Environmental Assessment and Management, Arctic 53(2): 183-193. http://www. jstor.org/stable/40512207

Wathne, J. A., Haug, T., Lydersen, C. (2000). Prey preference and niche overlap of ringed seals Phoca hispida and harp seal P. groenlandica in the Barents Sea, Marine Ecology Progress Series, 194: 233239. https://www.int-res.com/abstracts/meps/v194/p233-239/.

Weidick, A., Mikkelsen, N., Mayer, C., Podlech, S. (2004). Jakobshavn Isbræ, West Greenland: the 2002-2003 collapse and nomination for the UNESCO World Heritage List. GEUS Bulletin, 4, 85-88. https://doi.org/10.34194/geusb.v4.4792.

Publisher's Note Springer Nature remains neutral with regard to jurisdictional claims in published maps and institutional affiliations. 